\title{
Cassava Food balanced in Protein and Free of HCN
}

\author{
Nagib Nassar* \\ Professor Emeritus of UnB and Researcher Emeritus of CNPq, and Founding President of the philanthropic foundation FUNAGIB, \\ Brazil
}

*Corresponding author: Nagib Nassar, Professor Emeritus of UnB and Researcher Emeritus of CNPq, and Founding President of the philanthropic foundation FUNAGIB, Brazil

\begin{tabular}{|c|c|}
\hline ARTICLE INFO & ABSTRACT \\
\hline & $\begin{array}{l}\text { Citation: Nagib Nassar. Cassava Food balanced in Protein and Free of HCN. Biomed J Sci } \\
\text { \& Tech Res 37(1)-2021. BJSTR. MS.ID.005942. }\end{array}$ \\
\hline Published: 䧟 July 08, 2021 & \\
\hline
\end{tabular}

\section{Opinion}

In his classic, Geography of Hunger (1951), the eminent Agronomist and sociologist Pernambucano, Josué de Castro clearly pointed out the poor protein content of cassava, which is the main food in the entire northern east and north of Brazil. He explained that this crop which feeds more than one hundred million Brazilians and one billion of the humid tropics in Asia, Africa and Latin America is so poor in protein that it does not exceed $1 \%$ of its edible roots. He further explained that the crop provides more than $80 \%$ of the daily calories consumed by the people of the Northern east and the North. This lack of protein leads to serious illnesses for recent borns and children such as fibrosis of the lungs and liver and even affects the brain.

Castro's josue suggested adding beans to manioc to northern east food may compensate for the lack of protein in manioc. During our research program we obtained varieties of cassava up to 3 times protein content taking the level up to $4 \%$ but this does not resolve the problem as the level is still very low for human needs. The analysis of the leaves of the same crop showed them to be as rich as having $32 \%$ protein, and it seems that a radical solution has been reached. The addition of leaf flour to cassava flour with a $20 \%$ proportion heating the mixture up to $200 \mathrm{C}$ for 20 minutes increases protein in the mixture by up to $8 \%$ protein content and eliminate HCN totally i.e, slighly more than the $7 \%$ found in wheat and rice. The addition does not increase the cost of the daily consumption of cassava because its leaves have never been used by farmers and are normally dispensed.
The solution mainly benefits, in addition to adults, more than 20 million children and newborns who are most affected and vulnerable by nutritional disequilibrium. It benefit those who live under the poverty line and those who suffer from lack of protein, which is the basic nutritional element essential for healthy organic and mental growth. In this phase of growth, school meals have an essential role for future citizens because of what they offer in basic food necessary for growth.

The balanced meal mentioned above guarantees the quality needed for healthy growth and at the same time must be economically available and within the budgetary reach of states and cities municipalities. As this is a new idea that should be brought to the attention of the federal government in a way that convinces by its availability and ease of application, our foundation financed extension agencies in two main states of the country which are Mato Grosso and Paraná to implement the idea. This is an example for all states and for the government in the future. Our execution addresses municipalities to use in school lunch.

National attention to the subject is not only important to cover a geographically larger area but also to disseminate an innovative technique and method to enrich and balance popular food whose defective and unbalanced content affects a large part of the population. With new knowledge and new applications, Josué de Castro, if alive, should be able to correct his old concept of the $1950 \mathrm{~s}$ on hunger geography, as he did not imagine what we have found in the leaves of the plant of so much abundant protein. In addition 
to balanced food, we also supply the Amazon and Northern east regions with improved varieties with triple productivity. Increasing the productivity of this food culture should be a top priority for our country. An increase in productivity was and can still be achieved by taking advantage of the genetic potentiality of the crop, which promises up to 7 times the current average. The current national and international average is 14 tons per hectare and our improved varieties developed by the University of Brassilia can reach up to 120 tons per hectare.

\section{ISSN: 2574-1241}

DOI: $10.26717 /$ BJSTR.2021.37.005942

Nagib Nassar. Biomed J Sci \& Tech Res

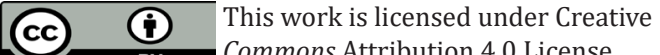

Submission Link: https://biomedres.us/submit-manuscript.php
The use of the rich Brazilian biodiversity will not only allow planting in arid areas that are not yet cultivated but also the development of varieties rich in up to 8 times the vitamin precursor beta-carotene. Other varieties developed by us are adapted too to severe environmental conditions.

\section{Conflict of Interests}

None.

$\begin{array}{ll}\text { BIOMEDICAL } & \text { Assets of Publishing with us } \\ \text { RESEARCHES } & \text { - Global archiving of articles } \\ & \text { - Immediate, unrestricted online access } \\ & \text { - Rigorous Peer Review Process } \\ & \text { - Authors Retain Copyrights }\end{array}$

